\title{
Animal Models of Parkinson's Disease
}

\author{
Elena A. Konnova • Maria Swanberg \\ Translational Neurogenetics Unit, Wallenberg Neuroscience Center, \\ Lund University, Lund, Sweden
}

Author for Correspondence: Maria Swanberg, Translational Neurogenetics Unit, Wallenberg Neuroscience Center, Lund University, Lund, Sweden. E-mail: maria.swanberg@med.lu.se

Doi: http://dx.doi.org/10.15586/codonpublications.parkinsonsdisease.2018.ch5

\begin{abstract}
Parkinson's disease (PD) is a heterogenous disease with a varying age of onset, symptoms, and rate of progression. This heterogeneity requires the use of a variety of animal models to study different aspects of the disease. Neurotoxin-based approaches include exposure of rodents or non-human primates to 6-OHDA, MPTP, and agrochemicals such as the pesticide rotenone, the herbicide paraquat, and the fungicide maneb. Acute exposure to neurotoxins induces motor deficits and rapid nigro-striatal dopaminergic cell death by disrupting mitochondrial function and/or increasing oxidative stress, while chronic administration of neurotoxins induces progressive models which can include alpha-synuclein ( $\alpha$-synuclein) aggregates. Genetic-based approaches to model Parkinson's disease include transgenic models and viral vectormediated models based on genes linked to monogenic Parkinson's disease, including SNCA, LRRK2, UCH-L1, PRKN, PINK1, and DJ-1, as well as manipulation of dopaminergic transcription factors. SNCA mutations, overexpression, and introduction of $\alpha$-synuclein preformed fibrils induce toxic protein aggregates and variable nigro-striatal neurodegeneration and motor deficits, depending on the specific model. Species, genetic background of a
\end{abstract}

\footnotetext{
In: Parkinson's Disease: Pathogenesis and Clinical Aspects. Stoker TB, Greenland JC (Editors). Codon Publications, Brisbane, Australia. ISBN: 978-0-9944381-6-4; Doi: http://dx.doi. org/10.15586/codonpublications.parkinsonsdisease.2018
}

Copyright: The Authors.

Licence: This open access article is licenced under Creative Commons Attribution 4.0 International (CC BY 4.0). https://creativecommons.org/licenses/by-nc/4.0/ 
strain, and environment affect the display of symptoms and neurodegenerative hallmarks of animal models. These models can be combined to study the interplay between genetics and environment and untangle the heterogeneity and mechanisms underlying Parkinson's disease. In this chapter, we discuss the strengths and limitations of mouse, rat, and non-human primate models of Parkinson's disease.

Keywords: Animal models; Genetic models; Neurotoxic models; Parkinson's disease; Non-human primates; Mouse, Rat

\section{INTRODUCTION}

Parkinson's disease (PD) is the second most common neurodegenerative disorder and is characterized by loss of nigro-striatal dopaminergic neurons and aggregation of the $\alpha$-synuclein-rich inclusions called Lewy bodies and Lewy neurites. The characteristic symptoms of PD are progressive motor deficits, including tremor, bradykinesia, akinesia, rigidity, postural instability, and gait difficulties. Nonmotor symptoms, including depression, anxiety, sleep disturbance, cognitive decline, and anosmia are also prevalent in PD patients, and often occur prior to the onset of motor symptoms (1).

Although around $10 \%$ of all PD cases have a monogenic origin, the majority are idiopathic, with multiple contributing environmental and genetic risk factors. Similar to the etiology, the clinical phenotype of PD is heterogeneous. While motor and non-motor symptoms are clinically detectable, the brain pathology in humans can only be confirmed by examining post-mortem tissues (2). Thus, there is a great need for experimental models to deepen our understanding of this multifaceted disease and expand the currently limited treatment options. The heterogeneity of both PD etiology and pathology requires a diverse range of models that can replicate different aspects of PD in animals (2).

Two main approaches are used to model PD in experimental animals: neurotoxins and genetics. Neurotoxins can model dopaminergic neurodegeneration arising from environmental factors that have been implicated in PD. They generally induce a strong and rapid cell loss in the substantia nigra pars compacta (SNpc), elicit motor symptoms and behavioral changes, but lack the formation of Lewy bodies (3). By contrast, genetic-based models not only demonstrate variable cell loss and motor symptoms but can also exhibit $\alpha$-synuclein pathology, depending on the specific model. Genetic mutations or changes in gene expression can be modeled using transgenic animals or be induced by viral transfection. Both neurotoxins and genetic approaches are applied in different animal species to model PD. This chapter provides an overview of the currently available animal models of PD.

\section{SPECIES-SPECIFIC CHARACTERISTICS}

There are three animal groups that are commonly used for modeling human diseases, and PD is no exception: rodents, non-human primates (NHP), and 
non-mammalian species. Each group has its own advantages and limitations that determine the suitability for a given experiment. Understanding species-specific differences therefore facilitates experimental design as well as interpretation of behavioral observations and pathophysiology.

\section{Rodents}

Rodents are extensively studied across biomedical fields because they are convenient to care for in laboratory conditions and have associated robust experimental protocols, including different forms of drug administration, generation of transgenic strains, and behavioral assessments. The majority of 23,000 animal studies of PD published since 1990 involve rodents (Figure 1). An advantage of rodent PD models is that nigro-striatal dopaminergic degeneration correlates to motor deficits in mice and rats. These can be observed and measured with a series of behavioral tests most of which involve measuring movement, grip, or strength of the front paws. Behavioral tests in rodents include the open field test for a general assessment of locomotor activity, the stepping test to measure akinesia, and the pole test to measure bradykinesia $(4,5)$. Strength is measured by grip strength and grip coordination tests (5). It is difficult to directly measure rigidity in rodents, but the performance on the rotarod test accounts for multiple factors such as balance, strength, and coordination (5).

Rodents with unilateral lesions will display asymmetric motor behavior where deficits in contralateral limb use can be measured and compared to the ipsilateral limb as an internal control. Drug-induced circling behavior is a more dramatic measure of a unilateral lesion $(5,6)$. In these tests, administration of amphetamine stimulates the release of dopamine in the intact contralateral side, resulting in ipsilateral rotation, while apomorphine causes contralateral rotations due to dopamine hypersensitivity of the lesioned side. Tremor and posture are often described qualitatively, and tremor monitors can be used to record shaking frequency (5). Gait can be assessed with paw print, but this is rarely done (5). Many of these motor tests can also be used to assess dyskinesia.

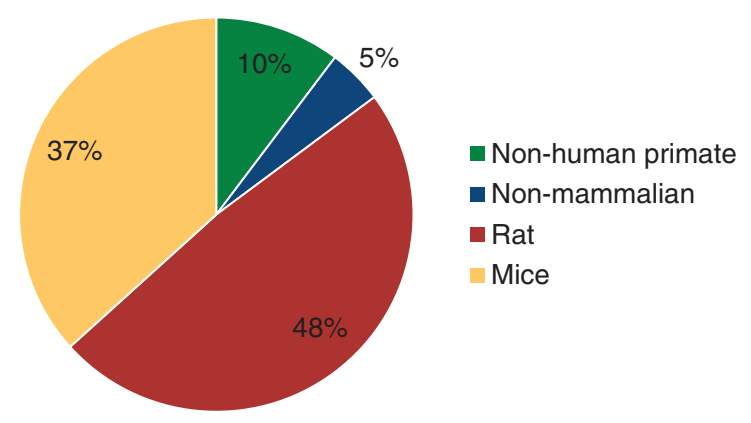

Figure 1 Proportion of animal models used in 23,000 research articles on Parkinson's disease published from January 1990 to June 2018. Numbers of original article publications were obtained from following searches on Web of Science: "Parkinson AND (mice OR mouse)"; "Parkinson AND rat"; "Parkinson AND (primate OR monkey)"; "Parkinson AND (non-mammalian OR drosophila OR elegans)." 
To study non-motor symptoms in rodents, the preferred method is using a model such as a partial nigro-striatal lesion, which does not cause concurrent motor deficits that may affect the test results. Sleeping, drinking, and eating patterns are monitored to assess sleep disturbance and weight loss (7). To model neuropsychiatric symptoms, a panel of complementary tests can be used, where the tail suspension test or the forced swim test is used to model depression or behavioral despair (7). Excessive grooming is a stereotypy signaling anxiety or compulsive behavior, and reduction in mouse species-specific nest building behavior can be used to model motivation and goal-oriented tasks (5).

\section{Non-human primates}

Studies of NHP give valuable insights into PD pathology owing to their anatomic and genetic similarity to humans (8). Compared to rodents, NHP are larger, have a longer life span, require more demanding care, incur higher costs, and involve more complex ethical considerations. Based on publications, only $10 \%$ of animal studies on PD are performed in NHP (Figure 1) and these are often reserved for preclinical evaluation of therapies (8). NHP models are currently based on neurotoxic or viral vector-mediated PD pathology, which generally induces parkinsonian symptoms and behaviors that are similar to those in humans. Therefore, a Unified Parkinson's Disease Rating Scale (UPDRS)-like measure can be used to assess the severity of the phenotype (9). However, unlike the clinical scale used for PD patients, these assessments are not standardized worldwide.

The NHP used most commonly in PD studies include macaques (10) followed by common marmosets. These species are convenient to use because of their smaller size, high reproductive efficiency, and relative ease of care and housing in laboratory conditions (11). Squirrel monkeys, African green monkeys, and baboons have also been used to model PD (10). PD models in the old world species such as macaques exhibit Levodopa-induced dyskinesia, similar to human chorea and dystonia, which are better distinguished than in new world monkeys such as marmosets (10). Other examples of NHP species-specific behavior include marmosets' jumping in the tower test to assess akinesia, and the righting reflex in the hourglass test to assess axial rigidity (12). Pre-diagnostic non-motor symptoms affecting sleep or social behavior have been preferentially studied in macaques since they are diurnal and better replicate human sleeping patterns, in contrast to rodents which have higher nocturnal activity (13). Social behavior changes, such as increased aggressiveness, can be assessed by monitoring facial expressions in female macaques (14).

In addition to behavioral assessments, NHP can be used for neuroimaging studies (15). These are especially valuable during preclinical drug trials, because these can be compared to patients during clinical phases (16). Thus, NHP models have many advantages but are demanding in terms of resources.

\section{Non-mammalian species}

Non-mammalian models, including drosophila and Caenorhabditis (C.) elegans, have been used in a small proportion of experimental PD studies over the past decades (Figure 1). These models, however, have several advantages such as easily generated genetic manipulations, a rapid reproductive cycle, low costs of maintenance, and well-defined neuropathology and behavior. 
A variety of transgenic drosophila and C. elegans models have been generated $(17,18)$. Due to the low cost and rapid completion of experiments, these models can be used for large screens for drug discovery. Furthermore, C. elegans models have the advantage of a fully mapped connectome possessing only 302 neurons, out of which only 8 are dopaminergic. Drosophila's larger connectome containing 135,000 neurons is also currently being mapped. Therefore, these models can be used to study fundamental principles governing cellular, genetic, and network changes resulting from dopaminergic loss. Since studies in non-mammalian species are, so far, used in a small fraction of PD models and can be challenging to translate to humans, this chapter will focus on the most commonly used neurotoxic and genetic PD models in rodents and NHP.

\section{NEUROTOXIC MODELS}

Several PD models are based on degeneration of dopaminergic neurons induced by local or systemic administration of neurotoxins. The first to be discovered was 6-hydroxydopamine (6-OHDA) (19), initially used in the periphery to degenerate sympathetic nerves (20), and later in the brain to model PD. The neurotoxin 1-methyl-4-phenyl-1,2,3,6-tetrahydropyridine (MPTP) was discovered through cases of chemically induced parkinsonism after failed synthesis of the opioid drug 1-methyl-4-phenyl-4-propionpiperidine (MPPP) (19). Reports of an increased risk of PD in populations exposed to pesticides for agricultural purposes (21) have resulted in additional neurotoxin-based PD models and studies on environmental risk factors of PD (Table 1).

\section{MPTP}

MPTP is a commonly used neurotoxin for modeling PD and can be administered acutely or chronically by different routes (22). It easily crosses the blood-brain barrier (BBB) within minutes due to its lipophilic nature. Glial cells take up MPTP, where it is converted first to 1-methyl-4-phenyl-2,3-dihydropyridinium (MPDP+) by monoamine oxidase- $\mathrm{B}(\mathrm{MAO}-\mathrm{B})$ followed by spontaneous oxidation into the toxic agent 1-methyl-4-phenylpyridinium (MPP+) (23). Once released back into the parenchyma through the organic cation transporter 3, MPP+ is transported selectively into dopaminergic cells through the dopamine transporter (DAT) and accumulates in the cytoplasm and in vesicular monoamine transporter (VMAT+) vesicles (24). MPP+ blocks mitochondrial complex I, which reduces ATP production, increases oxidative stress, and eventually causes cell death and neuroinflammation (23). This mechanism of action has contributed to the study of dopaminergic neurodegeneration, mitochondrial dysfunction, oxidative stress, and neuroinflammation in PD.

MPTP has been used to model PD in mice and NHP. However, rats are resistant to moderate doses of MPTP, while higher doses increase the mortality rates (26). The reliability and accessibility of the mouse MPTP model makes it a popular choice in PD research. The extent of the lesion depends on the dosage, route of administration, and the mouse strain used (33). Large lesions are useful to model late stages of PD for preclinical studies in drug discovery and development of other treatment strategies, such as deep brain stimulation (DBS), cell transplantation, 


\begin{tabular}{|c|c|c|c|}
\hline TABLE 1 & \multicolumn{3}{|c|}{$\begin{array}{l}\text { Summary of characteristics, uses, and limitations } \\
\text { of neurotoxic models }\end{array}$} \\
\hline PD model & Characteristics & Uses & Limitations \\
\hline $\begin{array}{l}\text { MPTP } \\
\text { Neurotoxin: } \\
\text { Inhibition of } \\
\quad \text { complex I } \\
\quad \text { (23) }\end{array}$ & $\begin{array}{l}\text { Acute dose: }(10,22) \\
\text { - No } \alpha \text {-synuclein aggregates } \\
\text { - Rapid and strong dopaminergic } \\
\quad \text { neurodegeneration } \\
\text { - Strong motor deficit } \\
\\
\text { Subacute/chronic dose: }(10,25) \\
\text { - Progressive model } \\
\text { - } \alpha \text {-synuclein aggregates } \\
\text { - No dopaminergic neurodegeneration } \\
\text { - No motor deficit }\end{array}$ & $\begin{array}{l}\text { - Common preclinical } \\
\text { model } \\
\text { - Systemic injection } \\
\text { (bilateral } \\
\text { parkinsonism) } \\
\text { - Used in mice and } \\
\text { NHP (24) }\end{array}$ & $\begin{array}{l}\text { - Rats are } \\
\text { resistant (26) } \\
\text { - Functional } \\
\text { recovery in } \\
\text { mice and NHP } \\
(5,10)\end{array}$ \\
\hline $\begin{array}{l}\text { 6-OHDA } \\
\text { Neurotoxin: } \\
\text { Inhibition of } \\
\text { complex } \\
\text { I and } \\
\text { oxidative } \\
\text { stress (19) }\end{array}$ & $\begin{array}{l}\text { Injection site-dependent lesion: (23) } \\
\text { - No } \alpha \text {-synuclein aggregates } \\
\text { - Rapid and strong dopaminergic } \\
\quad \text { neurodegeneration } \\
\text { - Strong asymmetric motor deficits }\end{array}$ & $\begin{array}{l}\text { - Common preclinical } \\
\text { model } \\
\text { - Intracranial injection } \\
\text { into SNpc, striatum, } \\
\text { or medial forebrain } \\
\text { bundle } \\
\text { - Hemiparkinsonism } \\
\text { (19) }\end{array}$ & $\begin{array}{l}\text { - High mortality } \\
\text { with bilateral } \\
\text { injection }(24)\end{array}$ \\
\hline $\begin{array}{l}\text { Rotenone } \\
\text { Pesticide: } \\
\text { Inhibition of } \\
\text { complex I }\end{array}$ & $\begin{array}{l}\text { - } \alpha \text {-synuclein aggregates } \\
\text { - Moderate dopaminergic } \\
\text { neurodegeneration } \\
\text { - Some motor deficits (27) }\end{array}$ & $\begin{array}{l}\text { - Model environmental } \\
\text { risks } \\
\text { - Evaluate risk of } \\
\text { pesticides }\end{array}$ & $\begin{array}{l}\text { - Toxicity in } \\
\text { humans } \\
\text { remains } \\
\text { controversial } \\
\text { (28) }\end{array}$ \\
\hline $\begin{array}{l}\text { Paraquat and } \\
\text { maneb } \\
\text { Herbicide and } \\
\text { fungicide: } \\
\text { Oxidative stress } \\
\text { (29) }\end{array}$ & $\begin{array}{l}\text { - } \alpha \text {-synuclein aggregates } \\
\text { - Some dopaminergic } \\
\text { neurodegeneration } \\
\text { - Some motor deficit }(30,31)\end{array}$ & $\begin{array}{l}\text { - Model environmental } \\
\text { risks } \\
\text { - Evaluate risk and } \\
\text { interaction of } \\
\text { pesticides }\end{array}$ & $\begin{array}{l}\text { - Toxicity in } \\
\text { humans } \\
\text { remains } \\
\text { controversial } \\
\text { (28) } \\
\text { - High doses of } \\
\text { paraquat cause } \\
\text { pulmonary } \\
\text { fibrosis (32) }\end{array}$ \\
\hline
\end{tabular}

NHP: non-human primates, SNpc: substantia nigra pars compacta.

and gene therapy (24). Most commonly, mice are administered an acute dose of MPTP by intraperitoneal (i.p.) injection which causes a loss of dopaminergic neurons, specifically in the SNpc rather than nearby regions such as the ventral tegmental area (VTA) (3). The neurodegeneration occurs within hours and stabilizes within 7 days. Four injections of an acute dose (up to $20 \mathrm{mg} / \mathrm{kg}$ ) with 2-hour intervals cause $90 \%$ of striatal dopamine depletion and $70 \%$ loss of dopaminergic neurons in the SNpc but no $\alpha$-synuclein aggregates (22).

MPTP-induced dopaminergic degeneration in mice correlates with motor deficits. However, these deficits can recover within a few days post-acute injection, which creates limitations on the duration of behavioral studies (5). The extent of 
degenerative effects of MPTP and functional recovery seems to be partially determined by the mouse strain used, that is, the genetic background (34). The MPTP model has also been used in studies on gut microbiota dysbiosis in PD. Fecal microbiota transplants from MPTP-treated mice reduced striatal dopamine levels and induced motor impairments in non-wild-type mice, while transplants of normal microbiota alleviated PD-like symptoms in MPTP-treated mice (35).

As an alternative to the acute mouse model, repeated daily i.p. injections of subacute doses result in delayed nigro-striatal neurodegeneration and progressive build-up of $\alpha$-synuclein inclusions $(25,36)$. The progressive nature of prolonged MPTP exposure in mice resembles PD, including neuroinflammation, $\alpha$-synuclein inclusion pathology, and molecular mechanism preceding cell death. By contrast, these models do not show apparent motor deficits.

MPTP is the gold standard for PD models in NHP (24). Most commonly, bilateral parkinsonism is induced through multiple low-dose systemic injections (10), but hemiparkinsonism can also be induced by intracarotid infusion (37). Usually, $1-2 \mathrm{mg} / \mathrm{kg}$ of MPTP is administered systemically over days to months. Symptoms develop over several months, and are then stable for another few months (10). A chronic MPTP model in NHP also exists, comparable to the subacute MPTP mouse models. This is induced in NHP by daily doses of MPTP of $0.2 \mathrm{mg} / \mathrm{kg}$ over 2-3 weeks and is used to model the progressive pre-symptomatic dopaminergic cell loss seen in early stages of PD (10). Just like with the MPTP mouse model, NHP recover function a few months post-injection (10). However, another round of MPTP exposure can be given to prolong the experiment.

Thus, in NHP, MPTP can cause dose-dependent dopaminergic degeneration in the SNpc and putamen as well as $\alpha$-synuclein aggregates that closely mimic PD pathology, and the extent of the lesion determines the severity of motor deficits (3). The neuropathology and symptoms are, however, more pronounced in PD patients (10). The presence of tremor correlates with the dopamine depletion in the basal ganglia and spontaneous firing, as seen in PD patients. Also, similar to PD patients, administration of L-dopa initially rescues motor deficit in NHP, but prolonged use elicits dyskinesia. Bilateral MPTP parkinsonism also displays some extra-nigral pathology, such as anosmia (38) and sleep disturbance (39). Thus, the resemblance of MPTP models in NHP to PD in humans makes them suitable for preclinical research of therapeutic strategies that have previously been validated in rodents.

\section{6-OHDA}

6-OHDA is an analogue of dopamine and norepinephrine. It is produced endogenously through the hydroxylation of dopamine metabolites and has been found in the human caudate nucleus $(6,24)$. 6-OHDA does not cross the BBB and needs to be administered directly into the brain to induce neurodegeneration. It enters dopaminergic and noradrenergic neurons through monoamine transporters; therefore, the injected solution must contain selective noradrenergic reuptake inhibitors (e.g., desipramine) to selectively target dopaminergic neurons (6). 6-OHDA induces cell death through oxidative stress by inhibiting mitochondrial complex I and by producing reactive oxygen species (ROS), such as superoxide radicals, hydroxyl radicals, and hydrogen peroxide (19). This reaction is catalyzed by iron, and toxicity can be prevented by iron chelating agents, such as 
vitamin E and MAO-B inhibitors (selegiline) (19). The specifics of 6-OHDA neurotoxicity remain poorly understood, but many antioxidant agents have neuroprotective effects.

Intracerebral 6-OHDA injections in rodents and NHP allow the targeting of the $\mathrm{SNpc}$, striatum, or medial forebrain bundle (23), and the generation of unilateral, hemiparkinsonian models (19). Bilateral injections often cause adipsia, aphagia, seizures, and high mortality (24). In rats, SNpc injections of 6-OHDA result in large dopaminergic degeneration within 24 hours and 90\% striatal dopamine loss within a couple of days $(6,23)$. However, injected in the striatum, 6-OHDA causes a retrograde degeneration of nigro-striatal neurons over a span of 1-3 weeks (23). Unilateral injections lead to asymmetric motor deficits and rotational behavior, also used to assess L-dopa-induced dyskinesia $(6,23)$. The unilateral models allow the use of the non-lesioned ipsilateral limbs as an internal control.

NHP require serial intracerebral 6-OHDA injections, which can result in postsurgical complications (15). In marmosets, nine striatal injections of $8 \mu \mathrm{g}$ 6-OHDA induced rotational behavior indicative of unilateral nigro-striatal lesion, but symptoms recovered after 10 weeks. Doubling the number of injections delayed functional recovery to 17 weeks post-surgery. 6-OHDA NHP models do not display $\alpha$-synuclein inclusions but have been used to study hyperactivity of the subthalamic nucleus, dyskinesia, anhedonia, and depressive behaviors (41). The 6-OHDA NHP models are also used to develop treatments, for example, DBS, neuroprotective agents, transplantation, and gene therapies $(42,43)$.

\section{Pesticides and herbicides}

The most recent and most debated neurotoxins used for modeling PD are pesticides and herbicides (44). Correlations between agro-chemical exposure in populations and increased risk for PD have been difficult to conclude due to a lack of details on exposure to particular agents (28). Emphasis has been made on rotenone, paraquat, and maneb as possible environmental causes of PD. So far, these pesticides and herbicides have been mostly used in rodents to try to model PD.

Both rotenone and paraquat are thought to cause dopaminergic degeneration by inducing oxidative stress. Rotenone probably acts through complex I, while paraquat exerts its toxicity through cellular redox cycling (29), despite being structurally similar to MPP+. It is still unclear how paraquat penetrates the BBB despite its high polarity (PQ2+). It seems that penetration is slow and inefficient as PET scans on macaques showed that the BBB prevents paraquat from penetrating the brain (45), and low levels of paraquat are seen after systemic exposure to rats (46). PQ2+ is not transported by DAT (47) but is converted to a monocation radical $\mathrm{PQ}+$ through redox cycling. $\mathrm{PQ}+$ seems to be the active agent penetrating the dopaminergic neurons through DAT and exerting cytotoxicity, as shown in cultured cells and mice (48). Despite the unclear mechanisms of action, rotenone and paraquat models are used to induce parkinsonian pathology and to study inhibition of inflammatory and oxidative stress pathways in adult rodents.

The rotenone rat model has gained some reliability as a pesticide model of PD due to its ability to cause dopaminergic degeneration, $\alpha$-synuclein inclusions, and motor deficits (27). Daily i.p. injections of $3 \mathrm{mg} / \mathrm{kg}$ of rotenone for $6-10$ days are sufficient to induce $45 \%$ loss of dopaminergic neurons in the SNpc, striatal 
dopamine depletion, and motor symptoms such as bradykinesia, postural instability, and rigidity (49). Rotenone can also induce non-motor symptoms such as sleep disturbances in rats (50).

Chronic paraquat administration in mice induces some dopaminergic cell loss in SNpc but does not cause dopamine depletion in the striatum or clear motor deficits (51). High doses of paraquat are not suitable for modeling PD, since they cause pulmonary fibrosis which could have secondary effects on behavior (32).

Pesticide models can increase the understanding of how environmental factors can affect PD risk. The primary research focus is on the mechanisms of action and the interaction with other risk factors, for example, genetic risk, age, and environmental exposure to other agro-chemicals. The combination of the herbicide paraquat and the fungicide maneb can elicit selective dopaminergic cell loss, dopamine depletion in the striatum, aggregation of $\alpha$-synuclein, as well as PD-like motor and non-motor symptoms in rodents. Repeated administration of $10 \mathrm{mg} / \mathrm{kg}$ paraquat and $30 \mathrm{mg} / \mathrm{kg}$ maneb to mice twice a week over the span of 6 weeks exacerbate parkinsonian pathology compared to each compound alone (30). The response to this combined exposure, however, varies between individuals from the outbred Sprague Dawley rat strain as a result of peripheral effects and/or genetics (31).

\section{GENETIC MODELS}

Genetics plays an important role in PD pathogenesis (see chapters 6 and 7). Disease-causing mutations have been identified through linkage analyses in familial PD, while genetic risk factors for idiopathic PD have been identified through association analyses in patients and controls (52). Monogenic PD can be inherited through autosomal dominant or autosomal recessive mutations with variable penetrance. However, de novo mutations of these genes can also be seen in patients with no family history of PD.

SNCA was the first gene to be linked to familial PD and together with the finding that the encoded protein $\alpha$-synuclein is aggregated in Lewy bodies, this led to a breakthrough in PD research $(53,54)$. Since then, a lot of research has focused on $\alpha$-synuclein models and pathology. The identification of additional monogenic PD mutations has been used to study the effects of mutated proteins and to develop new reliable animal models (Table 2). Most genetic models have only been effective at reproducing some of the PD hallmarks (Table 3). Development of new genetic tools, however, allows for the generation of new genetic-based models. One such example is viral vectors that can be used to introduce wild-type (WT) or mutated genes for targeted expression of a disease-associated protein.

\section{$\alpha$-synuclein and transgenic models}

Aggregated $\alpha$-synuclein protein is a main component of Lewy bodies in PD patients. The encoding gene, SNCA, was the first to be linked to familial PD, and was named PARKl (Table 2). Three autosomal dominant SNCA point mutations that are fully penetrant have been identified: A53T, A30P, and E46K $(62,73)$. 


\begin{tabular}{|c|c|c|c|c|}
\hline \multicolumn{2}{|c|}{ TABLE 2} & \multicolumn{3}{|c|}{$\begin{array}{l}\text { Summary of familial PD mutations that have been } \\
\text { replicated in animal models }\end{array}$} \\
\hline Locus & Gene & Mutation & Protein & Inheritance \\
\hline PARK1 & SNCA & A30P, A53T, E46K & $\alpha$-synuclein & Dominant \\
\hline PARK2 & PRKN & $\begin{array}{l}\text { Various mutations, exonic deletions, } \\
\text { duplication and triplication }\end{array}$ & Parkin & Recessive \\
\hline PARK4 & SNCA & Duplication and triplication & $\alpha$-synuclein & Dominant \\
\hline PARK5 & $\mathrm{UCH}-\mathrm{Ll}$ & I93M and S18Y & UCH-Ll & Dominant \\
\hline PARK6 & PINKl & G309D, exonic deletions & PINK1 & Recessive \\
\hline PARK7 & DJ-1 & Homozygous exon deletion, L166P & DJ-1 & Recessive \\
\hline PARK8 & LRRK2 & G2019S, R1441C/G, and others & Dardarin & Dominant \\
\hline
\end{tabular}

SNCA: $\alpha$-synuclein, UCH-Ll: ubiquitin carboxyl-terminal hydrolase isozyme L1, PINK1: serine/threonine-protein kinase PINK1, DJ-1: protein/nucleic acid deglycase DJ-1, LRRK2: leucine-rich repeat serine/threonine-protein kinase 2.

\begin{tabular}{|c|c|c|c|}
\hline TABLE 3 & \multicolumn{3}{|c|}{$\begin{array}{l}\text { Characteristics, uses, and limitations of genetic } \\
\text { models for Parkinson's disease }\end{array}$} \\
\hline PD model & Characteristics & Uses & Limitations \\
\hline $\begin{array}{l}\text { SNCA transgenic } \\
\text { rodents } \\
\text { Point mutations } \\
\text { (A53T, A30P, } \\
\text { E46K) and } \\
\text { overexpression of } \\
\alpha \text {-synuclein (ASO) }\end{array}$ & $\begin{array}{l}\text { Mice }(55) \text { and rats (56) } \\
\text { - Widespread } \alpha \text {-synuclein } \\
\text { aggregation } \\
\text { - No dopaminergic } \\
\text { neurodegeneration } \\
\text { - Some motor deficits }\end{array}$ & $\begin{array}{l}\text { - Models familial } \\
\text { mutations of SNCA } \\
\text { - Study } \alpha \text {-synuclein } \\
\text { function/ } \\
\text { propagation and } \\
\text { synucleiopathies }\end{array}$ & $\begin{array}{l}\text { - May affect } \\
\text { development } \\
(57) \\
\text { - No transgenic } \\
\text { NHP }\end{array}$ \\
\hline $\begin{array}{l}\text { Viral transfection of } \\
\alpha \text {-synuclein } \\
\text { Adeno-associated } \\
\text { virus and } \\
\text { lentivirus vectors }\end{array}$ & $\begin{array}{l}\text { Mice, rats, and NHP: (58) } \\
\text { - } \alpha \text {-synuclein aggregates } \\
\text { - Moderate dopaminergic } \\
\text { neurodegeneration } \\
\text { - Moderate motor deficits }\end{array}$ & $\begin{array}{l}\text { - Administered into } \\
\text { SNpc } \\
\text { - Study } \alpha \text {-synuclein } \\
\text { function, } \\
\text { propagation, and } \\
\text { synucleiopathies } \\
\text { - Potential } \\
\text { preclinical use }\end{array}$ & $\begin{array}{c}\text { - Potential vector } \\
\text { toxicity and } \\
\text { interference } \\
\text { of viral vector }\end{array}$ \\
\hline $\begin{array}{l}\alpha \text {-synuclein } \\
\text { preformed fibrils } \\
\text { Seeding of } \\
\alpha \text {-synuclein } \\
\text { aggregates }\end{array}$ & $\begin{array}{l}\text { Mice, rats (59), and NHP } \\
\quad(60) \text { : } \\
\text { - Widespread } \alpha \text {-synuclein } \\
\text { aggregation } \\
\text { - Mild dopaminergic } \\
\text { neurodegeneration } \\
\text { - Lack of motor deficits in rats } \\
\text { and NHP, some in mice }\end{array}$ & $\begin{array}{l}\text { - Administered to the } \\
\text { striatum (59) } \\
\text { - Study } \alpha \text {-synuclein } \\
\text { function/ } \\
\text { propagation and } \\
\text { synucleiopathies } \\
\text { - Can be combined } \\
\text { with } \alpha \text {-synuclein } \\
\text { viral vector (61) }\end{array}$ & $\begin{array}{l}\text { - Slow/weak } \\
\quad \text { onset of } \\
\text { pathology } \\
\text { (59) }\end{array}$ \\
\hline
\end{tabular}




\section{TABLE 3 Characteristics, uses, and limitations of genetic models for Parkinson's disease (Continued)}

\begin{tabular}{|c|c|c|c|}
\hline PD model & Characteristics & Uses & Limitations \\
\hline $\begin{array}{l}\text { LRRK2 } \\
\text { (WT, G2019S, } \\
\text { R1441C) } \\
\text { Transgenic and } \\
\text { viral vector- } \\
\text { mediated }\end{array}$ & $\begin{array}{l}\text { Mice and rats: }(3,62) \\
\text { - Affects inclusion formation } \\
\text { - Little dopaminergic } \\
\text { neurodegeneration } \\
\text { - Most lack motor deficits }\end{array}$ & $\begin{array}{l}\text { - Study the role } \\
\text { of LRRK2, its } \\
\text { interaction with } \\
\alpha \text {-synuclein, and } \\
\text { toxicity of mutant } \\
\text { LRRK2 }\end{array}$ & $\begin{array}{l}\text { - Large gene size } \\
\text { prevents the } \\
\text { use of AAV } \\
\text { vectors (58) } \\
\text { - No NHP } \\
\text { models }\end{array}$ \\
\hline $\begin{array}{l}\text { UCH-L1 } \\
\text { I93M mutation }\end{array}$ & $\begin{array}{l}\text { Mice: (63) } \\
\text { - No } \alpha \text {-synuclein aggregates } \\
\text { - Dopaminergic } \\
\quad \text { neurodegeneration } \\
\text { - Mild motor deficits }\end{array}$ & $\begin{array}{l}\text { - Study role of } \\
\text { UCH-Ll } \\
\text { - Used in combination } \\
\text { with } \alpha \text {-synuclein } \\
\text { and MPTP to study } \\
\text { interaction }\end{array}$ & $\begin{array}{l}\text { - Relevance to } \\
\text { pathogenesis } \\
\text { of PD is } \\
\text { debated (23) }\end{array}$ \\
\hline $\begin{array}{l}\text { Parkin, PINK, DJ-1 } \\
\text { Transgenic KO, } \\
\text { silencing, or } \\
\text { overexpression } \\
\text { using viral vectors }\end{array}$ & $\begin{array}{l}\text { Rodents: (62) } \\
\text { - Affects aggregation in } \\
\alpha \text {-synuclein models } \\
\text { - Most give no dopaminergic } \\
\text { neurodegeneration } \\
\text { - Lack clear motor deficits }\end{array}$ & $\begin{array}{l}\text { - Study role of Parkin, } \\
\text { PINK1, and DJ-1 } \\
\text { - Used in combination } \\
\text { with ASO or MPTP } \\
\text { models to study } \\
\text { interaction (64) }\end{array}$ & $\begin{array}{l}\text { - Large number } \\
\text { of identified } \\
\text { mutations } \\
(65) \\
\text {-No NHP } \\
\text { models }\end{array}$ \\
\hline $\begin{array}{l}\text { Nurrl (66), EN1 } \\
\text { (67), Pixt3 } \\
\text { (68), SHH (69), } \\
\text { MitoPark (70) } \\
\text { Transcription factor } \\
\text { deficiencies }\end{array}$ & $\begin{array}{l}\text { Mice: } \\
\text { - No } \alpha \text {-synuclein inclusions } \\
\text { - Dopaminergic } \\
\quad \text { neurodegeneration } \\
\text { - Motor deficits }\end{array}$ & $\begin{array}{l}\text { - Often heterozygous } \\
\text { KO or targeted to } \\
\text { dopamine neurons } \\
\text { (DAT-Cre mice) } \\
\text { - Study development } \\
\text { and maintenance } \\
\text { of the nigro-striatal } \\
\text { system }\end{array}$ & $\begin{array}{l}\text { - Not specific } \\
\text { for PD } \\
\text { - Nurrl and } \\
\text { Pixt3 models } \\
\text { also used for } \\
\text { schizophrenia } \\
(71,72)\end{array}$ \\
\hline
\end{tabular}

SNCA: $\alpha$-synuclein, ASO: $\alpha$-synuclein overexpression, LRRK2: leucine-rich repeat serine/threonine-protein kinase 2, WT: wild-type, UCH-Ll: ubiquitin carboxyl-terminal hydrolase isozyme L1, PINK1: serine/threonine-protein kinase PINK1, DJ-1: protein/nucleic acid deglycase DJ-1, Nurr1: nuclear receptor-related 1, EN1: engrailed-1, Pixt3: paired like homeodomain 3, NHP: non-human primate, SNpc: substantia nigra pars compacta, KO: knockout.

Many have made efforts to replicate familial PD by generating transgenic mice carrying these mutations. However, these transgenic models do not display clear dopaminergic neurodegeneration or parkinsonian motor deficits (55). Nonetheless, they show altered neuronal function and $\alpha$-synuclein aggregation. Mutated $\alpha$-synuclein also disrupts cellular processes such as autophagy in A30P and A53T in vitro models (74) and is associated with the formation of tau fibrillary tangles in E46K transgenic mice (75). Truncated forms of $\alpha$-synuclein are believed to be more toxic than full-length human $\alpha$-synuclein, and transgenic mice expressing truncated $\alpha$-synuclein show reduced number of nigro-striatal neurons due to cell loss during early development (57). Although these models are useful to elucidate the poorly understood $\alpha$-synuclein function and the relation of PD to other synucleinopathies, the clinical relevance of this model for PD is questionable since the transgene affects early developmental stages instead of modeling late onset 
neurodegeneration. As with other transgenic models, there is also a risk of compensatory mechanisms or additional deficits during development.

SNCA duplication or triplication (PARK4) is linked to PD with a dominant inheritance pattern (Table 2), showing that increased levels of WT $\alpha$-synuclein can cause Lewy body pathology and PD. Interestingly, common polymorphisms in the SNCA promoter affecting gene expression levels are also associated with the risk of developing idiopathic PD (76). $\alpha$-synuclein overexpression (ASO) can be modeled by knock-in transgene expression of human $\alpha$-synuclein in rodents (77). ASO rat and mouse models affect both the development and maintenance of dopaminergic neurons and are useful models for early PD, and to study pathological cascades arising from $\alpha$-synuclein. The spread of $\alpha$-synuclein aggregates in these models depends on the integration site, the promoter used to drive SNCA transcription, and on the genetic background (78). The Thyl promoter provides widespread SNCA expression and the formation of $\alpha$-synuclein aggregates in the brain. Thyl-ASO mice also display some motor symptoms and olfactory deficits but lack dopaminergic neurodegeneration (79). The Thyl-ASO model unfavorably expresses $\alpha$-synuclein in motor neurons in FVB mice but not in the C57Bl/6 background (77). In rats, the BAC-driven expression of E46K $\alpha$-synuclein lacks dopaminergic neurodegeneration but displays $\alpha$-synuclein aggregation, altered dopaminergic metabolism in the striatum, and evidence of oxidative stress (56).

\section{Viral vector-mediated models}

In addition to transgenic strains, $\alpha$-synuclein overexpression can be induced by viral vectors. The advantages of this method include targeting of the nigro-striatal system, the induction of pathology in adulthood, and the possibility to adjust dosage (58). Recombinant adeno-associated virus (rAAV) and lentivirus (LV)-based vectors have been used to transfer SNCA in rodents.

Different AAV serotypes have been used for human $\alpha$-synuclein transgene overexpression in the rat SNpc (59). Many have used AAV2 (59); however, the AAV6 serotype gave the largest dopaminergic cell loss (80\% after 8 weeks) and profound motor deficits (80). Using a LV vector also provides $\alpha$-synuclein aggregation but no clear dopaminergic cell loss or behavior changes with any of the $\alpha$-synuclein genotypes (58). In addition to the viral vector, the genetic variant of the $\alpha$-synuclein transgene influences the PD phenotype. rAAV-mediated expression of WT or A53T mutated $\alpha$-synuclein seem to elicit a comparable pathology, while the expression of A30P mutated $\alpha$-synuclein results in weaker and delayed pathology in rats $(58,81)$.

Efforts have been made to produce an equally strong rAAV- $\alpha$-synuclein model in mice as in rats; however, most mouse models display weak neurodegeneration and no clear $\alpha$-synuclein inclusions. Nevertheless, rAAV2/7- $\alpha$-synuclein transduction in the SNpc produced strong dose-dependent dopaminergic neurodegeneration after 8 weeks and motor deficits after 12 weeks (82).

Viral vector-mediated $\alpha$-synuclein models have also been applied to NHP. In the first model, rAAV2/2 vector was used to deliver WT or A53T $\alpha$-synuclein (83). Similar to mice, after 16 weeks, marmosets showed some variability (30-60\%) 
in nigral dopaminergic cell loss, with matching dopaminergic striatal depletion and mild motor deficits (83). This model did not show functional recovery by 42 weeks post-injection. A second rAAV1/2-A53T $\alpha$-synuclein NHP model has been produced and replicated in macaques (84). The macaque model displayed about 30\% loss of dopaminergic nigro-striatal neurons, about $50 \%$ DA depletion, and $40 \%$ reduction of DAT, resulting in ON-OFF display of bradykinesia.

If viral vector-mediated $\alpha$-synuclein models in NHP demonstrate robust motor deficits, they can become important preclinical models, complementing the current standard of MPTP-induced NHP models. The viral models have the advantage of producing $\alpha$-synuclein pathology and can lead to the development of treatments targeting $\alpha$-synuclein toxicity. A potential drawback of viral vectorbased models is the unfavorable interaction with subsequent viral transductions used in gene therapy. Exposure to the first viral vector may change the response to future exposure to viral vectors, altering transfection and the reliability of experimental results.

\section{Preformed fibril models}

Evidence of $\alpha$-synuclein toxicity, seeding, and anatomical spread (85) has led to the development of models directly introducing $\alpha$-synuclein protein fibrils into the brain. $\alpha$-synuclein is produced as a soluble protein that forms higher-order structures, including oligomers, fibrils, and filaments. Oligomeric structures seem to be the most toxic and aggregate into typical Lewy body inclusions. Mutations and truncations of $\alpha$-synuclein increase its misfolding, aggregation, and toxicity (86). Administration of exogenous $\alpha$-synuclein preformed fibrils (PFF), also called seeding, triggers formation of endogenous $\alpha$-synuclein aggregates $(59,87)$. This prion-like propagation has been used to produce PD models with widespread bilateral $\alpha$-synuclein inclusions to study their role in pathogenesis. In both mice and rats, introduction of $\alpha$-synuclein inclusions in the striatum causes neuronal dysfunction, mitochondrial damage, and eventual retrograde degeneration of nigro-striatal dopaminergic neurons $(88,89)$. However, mice display more robust bilateral motor deficits than rats (59). The combination of viral vectormediated overexpression of SNCA and seeding with PFF in rats induces progressive dopaminergic neurodegeneration and motor deficits alongside $\alpha$-synuclein aggregation (61).

Two NHP models with $\alpha$-synuclein fibrils have been published to date: macaques administered Lewy bodies extracted from PD patients into the striatum (60) and marmosets administered mouse A53T $\alpha$-synuclein into the caudate and putamen (90). The macaques lost striatal dopaminergic fibers by 4 months and displayed neurodegeneration in the SNpc after 17 months. The marmosets also showed signs of nigro-striatal dopaminergic neurodegeneration. Overall, both of these experiments demonstrate a benefit in modeling PD using $\alpha$-synuclein propagation, however, a limitation is that neither species showed clear motor deficits (91). The seeding of specific preformed structures of $\alpha$-synuclein is a promising method to further explore the function, propagation, and role of $\alpha$-synuclein in PD pathogenesis. 


\section{Autosomal dominant mutations: LRRK2 and UCH-L1}

LRRK2 was identified as a monogenic cause of PD in 2004 (92). LRRK2 mutations linked to PD display autosomal dominant inheritance, but with incomplete and varying penetrance, depending on the population. This means that not all mutation-carriers will develop PD (93). The most common LRRK2 mutations are G2019S and R1441C/G.

Most LRKK2 transgenic mouse and rat models have been unsuccessful in replicating PD hallmarks $(3,62)$. Some success has been achieved with BAC-LRRK2R1441G mice, which display some motor deficits and axonal pathology in the striatum, but lack clear dopaminergic neurodegeneration and formation of $\alpha$-synuclein inclusions (94). A combination of transgenic models can enhance PD-like pathology, and overexpression of LRRK2 in A53T $\alpha$-synuclein transgenic mice promoted dopaminergic degeneration and $\alpha$-synuclein aggregation (95).

Due to the large size of the LRRK2 gene, a limited number of viral models have been generated using herpes simplex virus (HSV) and adenoviral vectors (58). In rodents, transfection of LRRK2-G2019S is more toxic than WT LRRK2, causing more neurodegeneration and formation of inclusions (96). Injection of HSVLRRK2-G2019S in the mouse striatum has been shown to induce degeneration of about $50 \%$ of the dopaminergic neurons in the SNpc (97). LRRK2 models do not robustly replicate all PD hallmarks but are useful to understand the interplay between different genetic mutations and environmental factors and to untangle the mechanisms behind their functions in PD. Mutations in LRRK2 have not yet been used in PD models in NHP, but LRRK2 kinase inhibitors have been proposed as a potential therapeutic option in PD, and their effect has been explored in in macaques following MPTP exposure (98).

The pathogenic effects of UCH-Ll mutations have been debated due to their rarity in PD patients (23). However, transgenic mice with mutated UCH-Ll display a mild reduction in locomotion, reduced number of dopaminergic neurons in the SNpc, and dopamine depletion in the striatum, without $\alpha$-synuclein inclusions (63). Mutant UCH-Ll also exacerbates pathology in MPTP and ASO mouse models (64).

\section{Autosomal recessive mutations: PRKN, PINK1, and DJ-1}

Autosomal recessive mutations in PRKN (Parkin), PINK1, and DJ-1 have been linked to familial PD. There are over 100 known mutations of PRKN and it is the most commonly mutated gene in early onset PD (50\% of familial and 20\% of idiopathic early onset cases) (65). PINKl is the second most commonly mutated gene in early onset PD, present in $1-7 \%$ of the cases, while DJ-1 mutations are uncommon (81). Rare individuals who have two mutations in one of these three genes appear to have complete penetrance $(62,65,99)$.

Mutations in all three genes give loss-of-function, and therefore knockout models have been generated. However, none of the knockout models display dopaminergic cell loss or motor deficits (62). Some DJ-1 and PRKN models display changes in dopamine neurotransmission and mitochondrial dysfunction (100-102). Interestingly, overexpression of mutated PRKN-Q311X leads to agedependent dopaminergic neurodegeneration, $\alpha$-synuclein aggregation, and some motor deficits, suggesting a gain of pathological function (103). Backcrossing 
of DJ-1 nullizygous mice onto a C57Bl/6J background generates a new PD phenotype (104). These mice display strong early unilateral dopaminergic neurodegeneration that progresses into bilateral pathology in 15-month-old mice, demonstrating the age- and strain-dependent nature of some PD models.

Silencing gene expression of PINK1 or Parkin in adult mice using viral vectors has not yielded better PD models compared to knockout $(58,105)$, possibly because of less efficient silencing (86). However, both knockout and viral vectormediated knockdown of PINKl in mice rendered dopaminergic neurons more sensitive to MPTP $(58,105)$. PINKl knockout mice, but not PINKl silencing, enhanced neurodegeneration in the ASO model (106). Inactivation of PINK1 using RNA interference knocked down $71 \%$ of PINK1 in striatum and $68 \%$ in $\mathrm{SNpc}$ (86). These mice exhibited higher sensitivity to MPTP-induced neurodegeneration. Knockdown of DJ-1 also enhanced toxicity in the MPTP mouse model and could be rescued by reintroducing the gene with viral vectors (107). These examples of combinations of genetic and neurotoxic models highlight the complex interplay between multiple factors in PD pathology.

The overexpression of autosomal recessive genes, where loss-of-function is linked to PD, could become sources of treatments. For example, overexpression of PRKN via rAAV vectors had protective effects in the striatum of rAAV- $\alpha$ synuclein-treated NHP (108).

\section{Transcription factors}

Nuclear receptor-related 1 protein (Nurr1), engrailed 1 (EN1), pituitary homeobox 3 (Pitx3), sonic hedgehog (SHH), and c-Rel are all transcription factors that play a role in the development and maintenance of the dopaminergic nigro-striatal system (3). Nurrl knockout mice fail to differentiate dopaminergic neurons (109) and heterozygous Nurrl-deficient mice show a progressive dopaminergic cell loss $(3,66)$. DAT-Cre transgenic mice with Nurrl knockout in dopaminergic neurons display rapid striatal dopamine depletion, loss of SNpc dopaminergic neurons, and motor deficits $(110,111)$. Meanwhile, silencing Nurrl in dopaminergic neurons by using rAAV vectors gives progressive retrograde dopaminergic degeneration. However, none of the Nurrl-deficient models display $\alpha$-synuclein aggregates.

Heterozygous deficiency of EN1 gives rise to a progressive retrograde degeneration with dystrophy of striatal dopaminergic axons as early as at 4 weeks, and clear dopaminergic cell loss by 16 weeks accompanied by motor deficits and depressive-like behavioral changes $(67,112,113)$. The phenotype is seen in EN1heterozygous SwissOF1 mice, but not in C57Bl/6 with the same mutation. The neuroprotection in $\mathrm{C} 57 \mathrm{Bl} / 6$ is multigenic and could be useful for studying risk factors for idiopathic PD (114).

Knockout of c-Rel creates mice with disrupted production of cell survival factors (SOD2 and Bcl-xL). These mice have clear dopaminergic cell loss in the SNpc, dopamine depletion in the striatum, age-dependent motor deficits, and $\alpha$-synuclein aggregation in the SNpc (115). Pitx3 knockout mice, also called aphakia mice, have abnormal dopaminergic systems. They display strong dopaminergic degeneration in the SNpc, 90\% striatal dopamine depletion $(68,116)$, and clear motor deficits that are reversed with L-dopa administration (117). 
SHH has a vital role in the embryonic development of dopaminergic projections in the midbrain (118) and ablation of SHH in dopamine neurons causes dopaminergic and cholinergic neurotransmitter dysfunction, progressive neuronal loss, and motor deficits (69). The MitoPark model disrupts mitochondrial function in dopaminergic neurons by knocking out TFAM in DAT-Cre mice (62). These mice display progressive dopaminergic degeneration, motor impairments, and formation of inclusions that lack $\alpha$-synuclein $(41,70,119)$.

Transgenic mice with deficiencies in dopaminergic transcription factors have a role in modeling PD but display other dopaminergic pathologies that undermine their specificity. Nurrl and Pitx3 models have been suggested being applicable to cognitive disorders such as attention-deficit hyperactivity disorder (ADHD) and schizophrenia due to their involvement in other dopaminergic pathways (71, 72). Other transcription factors like SHH, TFAM, and NF-kB are relevant in the survival of many non-dopaminergic cells. These models can thus be useful to study defects in development and maintenance of dopaminergic neurons but are not specific to PD-related pathologies.

\section{CONCLUSION}

None of the animal models described above perfectly mimic the neuropathology of PD and the models cannot replicate the clinical syndrome. However, the wide variety of rodent, NHP, and non-mammalian models allows targeted studies of different pathological mechanisms of PD. The heterogeneity of these models can be seen as an advantage, since a clinical PD diagnosis reflects a heterogeneous group of patients with differences in onset, progression, symptoms, and neuropathology. The complex etiology of the disease, with interindividual variations in environmental and genetic risk factors, reflects the heterogeneity of PD and is seen both in idiopathic and monogenic cases. For example, some patients with DJ-1, Parkin, and LRRK2 mutations do not form Lewy bodies $(62,104)$. Diversifying the animal models can help understand various subtypes of PD and develop personalized treatments.

Current animal models of PD focus on degeneration of dopaminergic nigro-striatal neurons and formation of $\alpha$-synuclein aggregates, but many lack one or the other. Classical neurotoxins (MPTP and 6-OHDA) (24) in rodents and NHP, and transcription factor deficiencies-Nurrl (92), Pitx3 (68), SHH (69), MitoPark (102) —in mouse models cause an extensive loss of dopaminergic neurons in the $\mathrm{SNpc}$ and clear motor deficits but no $\alpha$-synuclein aggregation. In contrast, mutated $\alpha$-synuclein transgenic mouse models induce $\alpha$-synuclein aggregation without neurodegeneration (55). Other models have struck a balance between the aggregation of $\alpha$-synuclein and progressive degeneration of nigro-striatal neurons. These include chronic administration of MPTP in mice and $\operatorname{NHP}(10,25)$, pesticide and herbicide rodent models $(30,31,49)$, seeding of PFF in mice and NHP $(59,91)$, c-Rel knockout mice models (115), PRKN-Q311X overexpression (103), transfection of AAV- $\alpha$-synuclein in rodents and NHP $(80,82,84)$, and HSV- LRRK2 G2019S transfection in mice (97).

Furthermore, combined models can enhance PD hallmarks by hitting diseaseassociated pathways at several levels. For example, seeding of PFF in rats combined 
with rAAV- $\alpha$-synuclein transfection leads to enhanced $\alpha$-synuclein aggregation and neurodegeneration (61). Many transgenic models (mutated LRRK2 [3] and UCHL1 [63]; DJ-1, PINK1, and Parkin knockout [62]) show some functional disruption in the nigro-striatal system but have been ineffective at inducing a robust display of neurodegeneration and $\alpha$-synuclein pathology. However, UCHLl mutations, DJ-1 knockout and PINKl knockout, exacerbate ASO and MPTP mouse models $(64,86,107)$.

When choosing an animal model for PD, genetics of the selected species also needs to be taken into consideration, since the genetic background of mouse strains has been shown to alter the phenotype of different PD models. One example of strain effects on a monogenic PD model is the strain-dependent $\alpha$-synuclein toxicity in Thyl-ASO mice (77). Functional recovery in MPTP-exposed mice is also determined by the strain used, highlighting the importance of interaction of environmental factors with the genetic background (34). Attempts to map the genetic factors underlying strain-dependent susceptibility to PD-like phenotypes include linkage analysis in mice treated with MPTP (120) and paraquat (121) as well as in EN1-hemizygous mice (114). In addition, backcrossing DJ1-null mice to the $\mathrm{C} 57 \mathrm{Bl} / 6 \mathrm{~J}$ background generated a progressive unilateral to bilateral neurodegeneration in a subset of mice that segregated with exonic variants in five genes (104). Genes identified as conferring strain-dependent susceptibility to PD models are strong candidates as risk-modifying genes in PD.

Functional recovery in neurotoxic models and the lack of comparable phenotypes in mice carrying mutations that cause PD in humans highlight the difficulty of replicating PD in animal models. There is also a lack of models that include non-motor symptoms, which significantly affect the quality of life of patients with PD. This questions the relevance of animal PD models to human pathology. However, the development of PD models in NHP that have greater anatomic and genetic resemblance to humans, and new genetic technologies open new avenues towards creating models that display a complex pathology more similar to what is seen in PD patients (11). In addition, the panel of non-mammalian, rodent and NHP models offers the possibility to selectively study specific aspects of PD pathology. New technologies together with further refinement and combination of existing models could thus generate an array of animal models that can deepen our understanding of PD and help translate research into treatment.

Conflict of interest: The authors declare no potential conflict of interest with respect to research, authorship and/or publication of this manuscript.

Copyright and permission statement: To the best of our knowledge, the materials included in this chapter do not violate copyright laws. All original sources have been appropriately acknowledged and/or referenced. Where relevant, appropriate permissions have been obtained from the original copyright holder(s).

\section{REFERENCES}

1. Marras C, Chaudhuri KR. Nonmotor features of Parkinson's disease subtypes. Mov Disord. 2016 Aug;31(8):1095-102. https://doi.org/10.1002/mds.26510

2. Foltynie T, Brayne C, Barker RA. The heterogeneity of idiopathic Parkinson's disease. J Neurol. 2002 Feb;249(2):138-45. https://doi.org/10.1007/PL00007856 
3. Blesa J, Przedborski S. Parkinson's disease: Animal models and dopaminergic cell vulnerability. Front Neuroanat. 2014 Dec;8:155. https://doi.org/10.3389/fnana.2014.00155

4. Blume SR, Cass DK, Tseng KY. Stepping test in mice: A reliable approach in determining forelimb akinesia in MPTP-induced Parkinsonism. Exp Neurol. 2009 Sep;219(1):208-11. https://doi. org/10.1016/j.expneurol.2009.05.017

5. Sedelis M, Schwarting RK, Huston JP. Behavioral phenotyping of the MPTP mouse model of Parkinson's disease. Behav Brain Res. 2001 Nov;125(1-2):109-25. https://doi.org/10.1016/ S0166-4328(01)00309-6

6. Bove J, Perier C. Neurotoxin-based models of Parkinson's disease. Neuroscience. 2012 June;211:51-76. https://doi.org/10.1016/j.neuroscience.2011.10.057

7. Taylor TN, Greene JG, Miller GW. Behavioral phenotyping of mouse models of Parkinson's disease. Behav Brain Res. 2010 July;211(1):1-10. https://doi.org/10.1016/j.bbr.2010.03.004

8. Grow DA, McCarrey JR, CS Navara. Advantages of nonhuman primates as preclinical models for evaluating stem cell-based therapies for Parkinson's disease. Stem Cell Res. 2016 Sep;17(2):352-66. https://doi.org/10.1016/j.scr.2016.08.013

9. Imbert C, Bezard E, Guiltraud S, Boraud T, Gross CE. Comparison of eight clinical rating scales used for the assessment of MPTP-induced parkinsonism in the Macaque monkey. J Neurosci Methods. 2000 Mar;96(1):71-6. https://doi.org/10.1016/S0165-0270(99)00184-3

10. Fox SH, Brotchie JM. The MPTP-lesioned non-human primate models of Parkinson's disease. Past, present, and future. Prog Brain Res. 2010;184:133-57. https://doi.org/10.1016/ S0079-6123(10)84007-5

11. Yun JW, Ahn JB, Kang BC. Modeling Parkinson's disease in the common marmoset (Callithrix jacchus): Overview of models, methods, and animal care. Lab Anim Res. 2015 Dec;31(4):155-65. https://doi.org/10.5625/lar.2015.31.4.155

12. Verhave PS, Vanwersch RA, van Helden HP, Smit AB, Philippens IH. Two new test methods to quantify motor deficits in a marmoset model for Parkinson's disease. Behav Brain Res. 2009 June;200(1):214-19. https://doi.org/10.1016/j.bbr.2009.01.022

13. Barraud Q, Lambrecq V, Forni C, McGuire S, Hill M, Bioulac B, et al. Sleep disorders in Parkinson's disease: The contribution of the MPTP non-human primate model. Exp Neurol. 2009 Oct;219(2):574-82. https://doi.org/10.1016/j.expneurol.2009.07.019

14. Durand E, Petit O, Tremblay L, Zimmer C, Sgambato-Faure V, Chassain C, et al. Social behavioral changes in MPTP-treated monkey model of Parkinson's disease. Front Behav Neurosci. 2015 Feb;9:42. https://doi.org/10.3389/fnbeh.2015.00042

15. Emborg ME, Nonhuman primate models of Parkinson's disease. ILAR J. 2007;48(4):339-55. https:// doi.org/10.1093/ilar.48.4.339

16. Hallett PJ, Deleidi M, Astradsson A, Smith GA, Cooper O, Osborn TM, et al. Successful function of autologous iPSC-derived dopamine neurons following transplantation in a non-human primate model of Parkinson's disease. Cell Stem Cell. 2015 Mar;16(3):269-74. https://doi.org/10.1016/j. stem.2015.01.018

17. West RJ, Furmston R, Williams CA, Elliott CJ. Neurophysiology of Drosophila models of Parkinson's disease. Parkinsons Dis. 2015;2015:381281.

18. Cooper JF, Van Raamsdonk JM. Modeling Parkinson's disease in C. elegans. J Parkinsons Dis. 2018;8(1):17-32. https://doi.org/10.3233/JPD-171258

19. Schober A. Classic toxin-induced animal models of Parkinson's disease: 6-OHDA and MPTP. Cell Tissue Res. 2004 Oct;318(1):215-24. https://doi.org/10.1007/s00441-004-0938-y

20. Tieu K. A guide to neurotoxic animal models of Parkinson's disease. Cold Spring Harb Perspect Med. 2011 Sep;1(1):a009316. https://doi.org/10.1101/cshperspect.a009316

21. Costello S, Cockburn M, Bronstein J, Zhang X, Ritz B. Parkinson's disease and residential exposure to maneb and paraquat from agricultural applications in the central valley of California. Am J Epidemiol. 2009 Apr;169(8):919-26. https://doi.org/10.1093/aje/kwp006

22. Jackson-Lewis V, Przedborski S. Protocol for the MPTP mouse model of Parkinson's disease. Nat Protoc. 2007;2(1):141-51. https://doi.org/10.1038/nprot.2006.342

23. Dauer W, Przedborski S. Parkinson's disease: Mechanisms and models. Neuron. 2003 Sep;39(6):889-909. https://doi.org/10.1016/S0896-6273(03)00568-3 
24. Jackson-Lewis V, Blesa J, Przedborski S. Animal models of Parkinson's disease. Parkinsonism Relat Disord. 2012 Jan;18 Suppl 1:S183-5. https://doi.org/10.1016/S1353-8020(11)70057-8

25. Zhang QS, Heng Y, Mou Z, Huang JY, Yuan YH, Chen NH. Reassessment of subacute MPTP-treated mice as animal model of Parkinson's disease. Acta Pharmacol Sin. 2017 Oct;38(10):1317-28. https:// doi.org/10.1038/aps.2017.49

26. Giovanni A, Sieber BA, Heikkila RE, Sonsalla PK. Studies on species sensitivity to the dopaminergic neurotoxin 1-methyl-4-phenyl-1,2,3,6-tetrahydropyridine. Part 1: Systemic administration. J Pharmacol Exp Ther. 1994 Sep;270(3):1000-7.

27. Betarbet R, Sherer TB, MacKenzie G, Gracia-Osuna M, Panov AV, Greenamyre JT. Chronic systemic pesticide exposure reproduces features of Parkinson's disease. Nat Neurosci. 2000 Dec;3(12):1301-6. https://doi.org/10.1038/81834

28. Berry C, La Vecchia C, Nicotera P. Paraquat and Parkinson's disease. Cell Death Differ. 2010 July;17(7):1115-25. https://doi.org/10.1038/cdd.2009.217

29. Bonneh-Barkay D, Reaney SH, Langston WJ, Di Monte DA. Redox cycling of the herbicide paraquat in microglial cultures. Brain Res Mol Brain Res. 2005 Mar;134(1):52-6. https://doi.org/10.1016/j. molbrainres.2004.11.005

30. Thiruchelvam M, Richfield EK, Baggs RB, Tank AW, Cory-Slechta DA. The nigrostriatal dopaminergic system as a preferential target of repeated exposures to combined paraquat and maneb: Implications for Parkinson's disease. J Neurosci. 2000 Dec;20(24):9207-14. https://doi.org/10.1523/ JNEUROSCI.20-24-09207.2000

31. Tinakoua A, Bouabid S, Faggiani E, De Deurwaerdere P, Lakhdar-Ghazal N, Benazzouz A. The impact of combined administration of paraquat and maneb on motor and non-motor functions in the rat. Neuroscience. 2015 Dec;311:118-29. https://doi.org/10.1016/j.neuroscience.2015.10.021

32. Uversky VN. Neurotoxicant-induced animal models of Parkinson's disease: Understanding the role of rotenone, maneb and paraquat in neurodegeneration. Cell Tissue Res. 2004 Oct;318(1):225-41. https://doi.org/10.1007/s00441-004-0937-z

33. Sedelis M, Hofele K, Auburger GW, Morgan S, Huston JP, Schwarting RK. MPTP susceptibility in the mouse: Behavioral, neurochemical, and histological analysis of gender and strain differences. Behav Genet. 2000 May;30(3):171-82. https://doi.org/10.1023/A:1001958023096

34. Schwarting RK, Sedelis M, Hofele K, Auburger GW, Huston JP. Strain-dependent recovery of openfield behavior and striatal dopamine deficiency in the mouse MPTP model of Parkinson's disease. Neurotoxicity Res. 1999 Sep;1(1):41-56. https://doi.org/10.1007/BF03033338

35. Sun MF, Zhu YL, Zhou ZL, Jia XB, Xu YD, Yang Q, et al. Neuroprotective effects of fecal microbiota transplantation on MPTP-induced Parkinson's disease mice: Gut microbiota, glial reaction and TLR4/ TNF-alpha signaling pathway. Brain Behav Immun. 2018 May;70:48-60. https://doi.org/10.1016/j. bbi.2018.02.005

36. Vermilyea SC, Emborg ME. alpha-Synuclein and nonhuman primate models of Parkinson's disease. J Neurosci Methods. 2015 Nov;255:38-51. https://doi.org/10.1016/j.jneumeth.2015.07.025

37. Bankiewicz KS, Oldfield EH, Chiueh CC, Doppman JL, Jacobowitz DM, Kopin IJ. Hemiparkinsonism in monkeys after unilateral internal carotid artery infusion of 1-methyl-4-phenyl-1,2,3,6-tetrahydropyridine (MPTP). Life Sci. 1986 July;39(1):7-16. https://doi.org/10.1016/0024-3205(86)90431-5

38. Miwa T, Watanabe A, Mitsumoto Y, Furukawa M, Fukushima N, Moriizumi T. Olfactory impairment and Parkinson's disease-like symptoms observed in the common marmoset following administration of 1-methyl-4-phenyl-1,2,3,6-tetrahydropyridine. Acta Otolaryngol Suppl. 2004 Aug;(553):80-4. https://doi.org/10.1080/03655230410017724

39. Barcia C, Bautista V, Sanchez-Bahillo A, Fernandez-Villalba E, Navarro-Ruis JM, Barreiro AF, et al. Circadian determinations of cortisol, prolactin and melatonin in chronic methyl-phenyl-tetrahydropyridine-treated monkeys. Neuroendocrinology. 2003 Aug;78(2):118-28. https://doi.org/10.1159/000071967

40. Eslamboli A, Georgievska B, Ridley RM, Baker HF, Muzyczka N, Burger C, et al. Continuous low-level glial cell line-derived neurotrophic factor delivery using recombinant adeno-associated viral vectors provides neuroprotection and induces behavioral recovery in a primate model of Parkinson's disease. J Neurosci. 2005 Jan;25(4):769-77. https://doi.org/10.1523/JNEUROSCI.4421-04.2005

41. Gubellini P, Kachidian P. Animal models of Parkinson's disease: An updated overview. Rev Neurol (Paris). 2015 Nov;171(11):750-61. https://doi.org/10.1016/j.neurol.2015.07.011 
42. Kirik D, Georgievska B, Burger C, Winkler C, Muzyczka N, Mandel RJ, et al. Reversal of motor impairments in parkinsonian rats by continuous intrastriatal delivery of L-dopa using rAAVmediated gene transfer. Proc Natl Acad Sci U S A. 2002 Apr;99(7):4708-13. https://doi.org/10.1073/ pnas.062047599

43. Bjorklund LM, Sanchez-Perneute R, Chung S, Andersson T, Chen IY, McNaught KS, et al. Embryonic stem cells develop into functional dopaminergic neurons after transplantation in a Parkinson rat model. Proc Natl Acad Sci U S A. 2002 Feb;99(4):2344-9. https://doi.org/10.1073/pnas.022438099

44. Kamel F. Epidemiology. Paths from pesticides to Parkinson's. Science. 2013 Aug;341(6147):722-3. https://doi.org/10.1126/science.1243619

45. Bartlett RM, Holden JE, Nickles RJ, Murali D, Barbee DL, Bamhart TE, et al. Paraquat is excluded by the blood brain barrier in rhesus macaque: An in vivo pet study. Brain Res. 2009 Mar;1259:74-9. https://doi.org/10.1016/j.brainres.2008.12.033

46. Naylor JL, Widdowson PS, Simpson MG, Farnworth M, Ellis MK, Lock EA, et al. Further evidence that the blood/brain barrier impedes paraquat entry into the brain. Hum Exp Toxicol. 1995 July;14(7):587-94. https://doi.org/10.1177/096032719501400706

47. Richardson JR, Quan Y, Sherer TB, Greenamyre JT, Miller GW. Paraquat neurotoxicity is distinct from that of MPTP and rotenone. Toxicol Sci. 2005 Nov;88(1):193-201. https://doi.org/10.1093/toxsci/ kfi304

48. Rappold PM, Cui M, Chesser AS, Tibbett J, Grima JC, Duan L, et al. Paraquat neurotoxicity is mediated by the dopamine transporter and organic cation transporter-3. Proc Natl Acad Sci U S A. 2011 Dec;108(51):20766-71. https://doi.org/10.1073/pnas.1115141108

49. Cannon JR, Tapias V, Na HM, Honick AS, Drolet RE, Greenamyre JT. A highly reproducible rotenone model of Parkinson's disease. Neurobiol Dis. 2009 May;34(2):279-90. https://doi.org/10.1016/j. nbd.2009.01.016

50. Garcia-Garcia F, Ponce S, Brown R, Cussen V, Krueger JM. Sleep disturbances in the rotenone animal model of Parkinson disease. Brain Res. 2005 May;1042(2):160-8. https://doi.org/10.1016/j. brainres.2005.02.036

51. McCormack AL, Thiruchelvam M, Manning-Bog AB, Thiffault C, Langston JW, Cory-Slechta DA, et al. Environmental risk factors and Parkinson's disease: Selective degeneration of nigral dopaminergic neurons caused by the herbicide paraquat. Neurobiol Dis. 2002 July;10(2):119-27. https://doi. org/10.1006/nbdi.2002.0507

52. Billingsley KJ, Bandres-Ciga S, Saez-Atienzar S, Singleton AB. Genetic risk factors in Parkinson's disease. Cell Tissue Res. 2018 July;373(1):9-20. https://doi.org/10.1007/s00441-018-2817-y

53. Spillantini MG, Schmidt ML, Lee VM, Trojanowski JQ, Jakes R, Goedert M. $\alpha$-Synuclein in Lewy bodies. Nature. 1997 Aug;388:839. https://doi.org/10.1038/42166

54. Polymeropoulos MH, Lavedan C, Leroy E, Ide SE, Dehajia A, Durta A, et al. Mutation in the alphasynuclein gene identified in families with Parkinson's disease. Science. 1997 June;276(5321):2045-7. https://doi.org/10.1126/science.276.5321.2045

55. Fleming SM, Fernagut PO, Chesselet MF. Genetic mouse models of parkinsonism: Strengths and limitations. NeuroRx. 2005 July;2(3):495-503. https://doi.org/10.1602/neurorx.2.3.495

56. Cannon JR, Geghman KD, Tapias V, Sew T, Dail MK, Li C, et al. Expression of human E46K-mutated alpha-synuclein in BAC-transgenic rats replicates early-stage Parkinson's disease features and enhances vulnerability to mitochondrial impairment. Exp Neurol. 2013 Feb;240:44-56. https://doi. org/10.1016/j.expneurol.2012.11.007

57. Wakamatsu M, Ishii A, Iwata S, Sakagami J, Ukai Y, Ono M, et al. Selective loss of nigral dopamine neurons induced by overexpression of truncated human alpha-synuclein in mice. Neurobiol Aging. 2008 Apr;29(4):574-85. https://doi.org/10.1016/j.neurobiolaging.2006.11.017

58. Van der Perren A, Van den Haute C, Baekelandt V. Viral vector-based models of Parkinson's disease. Curr Top Behav Neurosci. 2015;22:271-301. https://doi.org/10.1007/7854_2014_310

59. Volpicelli-Daley LA, Kirik D, Stoyka LE, Standaert DG, Harms AS. How can rAAV-alpha-synuclein and the fibril alpha-synuclein models advance our understanding of Parkinson's disease? J Neurochem. 2016 Oct;139 Suppl 1:131-55. https://doi.org/10.1111/jnc.13627

60. Recasens A, Dehay B, Bove J, Carballo-Carbajal I, Dovero S, Perez-Villalba A, et al. Lewy body extracts from Parkinson disease brains trigger alpha-synuclein pathology and neurodegeneration in mice and monkeys. Ann Neurol. 2014 Mar;75(3):351-62. https://doi.org/10.1002/ana.24066 
61. Thakur P, Breger LS, Lundblad M, Wan OW, Mattsson B, Luk KC, et al. Modeling Parkinson's disease pathology by combination of fibril seeds and alpha-synuclein overexpression in the rat brain. Proc Natl Acad Sci U S A. 2017 Sep;114(39):E8284-93. https://doi.org/10.1073/pnas.1710442114

62. Dawson TM, Ko HS, Dawson VL. Genetic animal models of Parkinson's disease. Neuron. 2010 June;66(5):646-61. https://doi.org/10.1016/j.neuron.2010.04.034

63. Setsuie R, Wang YL, Mochizuki H, Osaka H, Hayakawa H, Ichihara N, et al. Dopaminergic neuronal loss in transgenic mice expressing the Parkinson's disease-associated UCH-Ll I93M mutant. Neurochem Int. 2007 Jan;50(1):119-29. https://doi.org/10.1016/j.neuint.2006.07.015

64. Yasuda T, Nihira T, Ren YR, Cao XQ, Wada K, Setsule R, et al. Effects of UCH-Ll on alpha-synuclein over-expression mouse model of Parkinson's disease. J Neurochem. 2009 Feb;108(4):932-44. https:// doi.org/10.1111/j.1471-4159.2008.05827.x

65. Lucking CB, Durr A, Bonifati V, Vaughan J, De Michele G, Gasser T, et al. Association between earlyonset Parkinson's disease and mutations in the parkin gene. N Engl J Med. 2000 May;342(21):1560-7. https://doi.org/10.1056/NEJM200005253422103

66. Jiang C, Wan X, He Y, Pan T, Jankovic J, Le W. Age-dependent dopaminergic dysfunction in Nurrl knockout mice. Exp Neurol. 2005. 191(1):154-62. https://doi.org/10.1016/j.expneurol. 2004.08.035

67. Sonnier L, Le Pen G, Hartmann A, Bizot JC, Trovero F, Krebs MO, et al. Progressive loss of dopaminergic neurons in the ventral midbrain of adult mice heterozygote for Engrailedl. J Neurosci. 2007 Jan;27(5):1063-71. https://doi.org/10.1523/JNEUROSCI.4583-06.2007

68. Hwang DY, Ardayfio P, Kang UJ, Semina EV, Kim KS. Selective loss of dopaminergic neurons in the substantia nigra of Pitx3-deficient aphakia mice. Brain Res Mol Brain Res. 2003 June;114(2):123-31. https://doi.org/10.1016/S0169-328X(03)00162-1

69. Gonzalez-Reyes LE, Verbitsky M, Blesa J, Jackson-Lewis V, Paredes D, Tillack K, et al. Sonic hedgehog maintains cellular and neurochemical homeostasis in the adult nigrostriatal circuit. Neuron. 2012 July;75(2):306-19. https://doi.org/10.1016/j.neuron.2012.05.018

70. Ekstrand MI, Terzioglu M, Galter D, Zhu S, Hofstetter C, Lindqvist E, et al. Progressive parkinsonism in mice with respiratory-chain-deficient dopamine neurons. Proc Natl Acad Sci U S A. 2007 Jan;104(4):1325-30. https://doi.org/10.1073/pnas.0605208103

71. Rojas P, Joodmardi E, Hong Y, Perlmann T, Ogren SO. Adult mice with reduced Nurrl expression: An animal model for schizophrenia. Mol Psychiatry. 2007 Aug;12(8):756-66. https://doi.org/10.1038/ sj.mp. 4001993

72. Ardayfio PA, Leung A, Park J, Hwang DY, Moran-Gates T, Choi YK, et al. Pitx3-deficient aphakia mice display unique behavioral responses to psychostimulant and antipsychotic drugs. Neuroscience. 2010 Mar;166(2):391-6. https://doi.org/10.1016/j.neuroscience.2009.12.033

73. Zarranz JJ, Alegre J, Gomez-Esteban JC, Lezcano E, Ros R, Ampuero I, et al. The new mutation, E46K, of alpha-synuclein causes Parkinson and Lewy body dementia. Ann Neurol. 2004 Feb;55(2):164-73. https://doi.org/10.1002/ana.10795

74. Cuervo AM, Stefanis L, Fredenburg R, Lansbury PT, Sulzer D. Impaired degradation of mutant alphasynuclein by chaperone-mediated autophagy. Science. 2004 Aug;305(5688):1292-5. https://doi. org/10.1126/science.1101738

75. Emmer KL, Waxman EA, Covy JP, Giasson BI. E46K human alpha-synuclein transgenic mice develop Lewy-like and tau pathology associated with age-dependent, detrimental motor impairment. J Biol Chem. 2011 Oct;286(40):35104-18. https://doi.org/10.1074/jbc.M111.247965

76. Chang D, Nalls MA, Hallgrimsdottir IB, Hunkapiller J, van der Brug M, Cai F, et al. A meta-analysis of genome-wide association studies identifies 17 new Parkinson's disease risk loci. Nat Genet. 2017 Oct;49(10):1511-16. https://doi.org/10.1038/ng.3955

77. Chesselet MF, Fleming S, Mortazavi F, Meurers B. Strengths and limitations of genetic mouse models of Parkinson's disease. Parkinsonism Relat Disord. 2008;14 Suppl 2:S84-7. https://doi.org/10.1016/j. parkreldis.2008.04.004

78. Magen I, Chesselet MF. Genetic mouse models of Parkinson's disease The state of the art. Prog Brain Res. 2010;184:53-87. https://doi.org/10.1016/S0079-6123(10)84004-X

79. Chesselet MF, Richter F, Zhu C, Magen I, Watson MB, Subramaniam SR. A progressive mouse model of Parkinson's disease: The Thyl-aSyn ("Line 61") mice. Neurotherapeutics. 2012 Apr;9(2):297-314. https://doi.org/10.1007/s13311-012-0104-2 
80. Decressac M, Mattsson B, Lundblad M, Weikop P, Bjorklund A. Progressive neurodegenerative and behavioural changes induced by AAV-mediated overexpression of alpha-synuclein in midbrain dopamine neurons. Neurobiol Dis. 2012 Mar;45(3):939-53. https://doi.org/10.1016/j. nbd.2011.12.013

81. Kirik D, Rosenblad C, Burger C, Lundberg C, Johansen TE, Muzyczka N, et al. Parkinson-like neurodegeneration induced by targeted overexpression of alpha-synuclein in the nigrostriatal system. J Neurosci. 2002 Apr;22(7):2780-91. https://doi.org/10.1523/JNEUROSCI.22-07-02780.2002

82. Oliveras-Salva M, Van der Perren A, Casadei N, Stroobants S, Nuber S, D'Hooge R, et al. rAAV2/7 vector-mediated overexpression of alpha-synuclein in mouse substantia nigra induces protein aggregation and progressive dose-dependent neurodegeneration. Mol Neurodegener. 2013 Nov;8:44. https://doi.org/10.1186/1750-1326-8-44

83. Kirik D, Annett LE, Burger C, Muzyczka N, Mandel RJ, Bjorklund A. Nigrostriatal alpha-synucleinopathy induced by viral vector-mediated overexpression of human alpha-synuclein: A new primate model of Parkinson's disease. Proc Natl Acad Sci U S A. 2003 Mar;100(5):2884-9. https://doi. org/10.1073/pnas.0536383100

84. Koprich J, Johnston T, Howson P, Reyes G, Omana V, Brotchie J. Characterization and reproducibility of a macaque model of Parkinson's disease alpha-synucleinopathy. Parkinsonism Relat Disord. 2018 Jan;46:e3-4. https://doi.org/10.1016/j.parkreldis.2017.11.012

85. Li JY, Englund E, Holton JL, Soulet D, Hagell P, Lees AJ, et al. Lewy bodies in grafted neurons in subjects with Parkinson's disease suggest host-to-graft disease propagation. Nat Med. 2008 May;14(5):501-3. https://doi.org/10.1038/nm1746

86. Luna E, Luk KC. Bent out of shape: Alpha-Synuclein misfolding and the convergence of pathogenic pathways in Parkinson's disease. FEBS Lett. 2015 Dec;589(24 Pt A):3749-59. https://doi. org/10.1016/j.febslet.2015.10.023

87. Volpicelli-Daley LA, Luk KC, Lee VM. Addition of exogenous alpha-synuclein preformed fibrils to primary neuronal cultures to seed recruitment of endogenous alpha-synuclein to Lewy body and Lewy neurite-like aggregates. Nat Protoc. 2014 Sep;9(9):2135-46. https://doi.org/10.1038/nprot.2014.143

88. Luk KC, Kehm V, Carroll J, Zhang B, O’Brien P, Trojanowski JQ, et al. Pathological alpha-synuclein transmission initiates Parkinson-like neurodegeneration in nontransgenic mice. Science. 2012 Nov;338(6109):949-53. https://doi.org/10.1126/science.1227157

89. Grassi D, Howard S, Zhou M, Diaz-Perez N, Urban NT, Guerrero-Given D, et al. Identification of a highly neurotoxic alpha-synuclein species inducing mitochondrial damage and mitophagy in Parkinson's disease. Proc Natl Acad Sci U S A. 2018 Mar;115(11):E2634-43. https://doi.org/10.1073/ pnas. 1713849115

90. Shimozawa A, Ono M, Takahara D, Tarutani A, Imura S, Masuda-Suzukake M, et al. Propagation of pathological alpha-synuclein in marmoset brain. Acta Neuropathol Commun. 2017 Feb;5(1):12. https://doi.org/10.1186/s40478-017-0413-0

91. Marmion DJ, Kordower JH. alpha-Synuclein nonhuman primate models of Parkinson's disease. J Neural Transm (Vienna). 2018 Mar;125(3):385-400. https://doi.org/10.1007/s00702-017-1720-0

92. Zimprich A, Biskup S, Leitner P, Lichtner P, Farrer M, Lincoln S, et al. Mutations in LRRK2 cause autosomal-dominant parkinsonism with pleomorphic pathology. Neuron. 2004 Nov;44(4):601-7. https://doi.org/10.1016/j.neuron.2004.11.005

93. Alessi DR, Sammler E. LRRK2 kinase in Parkinson's disease. Science. 2018 Apr;360(6384):36-7. https://doi.org/10.1126/science.aar5683

94. Li Y, Liu W, Oo TH, Wanh L, Tang Y, Jackson-Lewis V, et al. Mutant LRRK2(R1441G) BAC transgenic mice recapitulate cardinal features of Parkinson's disease. Nat Neurosci. 2009 July;12(7):826-8. https://doi.org/10.1038/nn.2349

95. Lin X, Parisiadou L, Gu XL, Wang L, Shim H, Sun L, et al. Leucine-rich repeat kinase 2 regulates the progression of neuropathology induced by Parkinson's-disease-related mutant alpha-synuclein. Neuron. 2009 Dec;64(6):807-27. https://doi.org/10.1016/j.neuron.2009.11.006

96. Dusonchet J, Kochubey O, Stafa K, Young SM Jr, Zufferey R, Moore DJ, et al. A rat model of progressive nigral neurodegeneration induced by the Parkinson's disease-associated G2019S mutation in LRRK2. J Neurosci. 2011 Jan;31(3):907-12. https://doi.org/10.1523/JNEUROSCI.5092-10.2011 
97. Lee BD, Shin JH, VanKampen J, Petrucelli L, West AB, Ko HS, et al. Inhibitors of leucine-rich repeat kinase-2 protect against models of Parkinson's disease. Nat Med. 2010 Sep;16(9):998-1000. https:// doi.org/10.1038/nm.2199

98. Henderson JL, Kormos BL, Hayward MM, Coffman KJ, Jasti J, Kurumbail RG, et al. Discovery and preclinical profiling of 3-[4-(morpholin-4-yl)-7H-pyrrolo[2,3-d]pyrimidin-5-yl]benzonitrile (PF06447475), a highly potent, selective, brain penetrant, and in vivo active LRRK2 kinase inhibitor. J Med Chem. 2015 Jan;58(1):419-32. https://doi.org/10.1021/jm5014055

99. Gasser T. Molecular pathogenesis of Parkinson disease: Insights from genetic studies. Expert Rev Mol Med. 2009 July;11:e22. https://doi.org/10.1017/S1462399409001148

100. Goldberg MS, Pisani A, Haburcak M, Vortherms TA, Kitada T, Costa C, et al. Nigrostriatal dopaminergic deficits and hypokinesia caused by inactivation of the familial Parkinsonism-linked gene DJ-1. Neuron. 2005 Feb;45(4):489-96. https://doi.org/10.1016/j.neuron.2005.01.041

101. Andres-Mateos E, Perier C, Zhang L, Blanchard-Fillion B, Greco TM, Thomas B, et al. DJ-1 gene deletion reveals that DJ-1 is an atypical peroxiredoxin-like peroxidase. Proc Natl Acad Sci U S A. 2007 Sep;104(37):14807-12. https://doi.org/10.1073/pnas.0703219104

102. Palacino JJ, Sagi D, Goldberg MS, Krauss S, Motz C, Wacker M, et al. Mitochondrial dysfunction and oxidative damage in parkin-deficient mice. J Biol Chem. 2004 Apr;279(18):18614-22. https://doi. org/10.1074/jbc.M401135200

103. Lu XH, Fleming SM, Meurers B, Ackerson LC, Mortazavi F, Lo V, et al. Bacterial artificial chromosome transgenic mice expressing a truncated mutant parkin exhibit age-dependent hypokinetic motor deficits, dopaminergic neuron degeneration, and accumulation of proteinase K-resistant alpha-synuclein. J Neurosci. 2009 Feb;29(7):1962-76. https://doi.org/10.1523/JNEUROSCI.5351-08.2009

104. Rousseaux MW, Maracogliese PC, Qu D, Hewitt SJ, Seang S, Kim RH, et al. Progressive dopaminergic cell loss with unilateral-to-bilateral progression in a genetic model of Parkinson disease. Proc Natl Acad Sci U S A. 2012 Sep;109(39):15918-23. https://doi.org/10.1073/pnas.1205102109

105. Haque ME, Mount MP, Safarpour F, Abdel-Messih E, Callaghan S, Mazerolle C, et al. Inactivation of Pinkl gene in vivo sensitizes dopamine-producing neurons to 1-methyl-4-phenyl-1,2,3,6tetrahydropyridine (MPTP) and can be rescued by autosomal recessive Parkinson disease genes, Parkin or DJ-1. J Biol Chem. 2012 June;287(27):23162-70. https://doi.org/10.1074/jbc.M112.346437

106. Oliveras-Salva M, Macchi F, Coessens V, Deleersnijder A, Gerard M, Van der Perren A, et al. Alphasynuclein-induced neurodegeneration is exacerbated in PINKl knockout mice. Neurobiol Aging. 2014 Nov;35(11):2625-36. https://doi.org/10.1016/j.neurobiolaging.2014.04.032

107. Kim RH, Smith PD, Aleyasin H, Hayley S, Mount MP, Pownall S, et al. Hypersensitivity of DJ-1deficient mice to 1-methyl-4-phenyl-1,2,3,6-tetrahydropyrindine (MPTP) and oxidative stress. Proc Natl Acad Sci U S A. 2005 Apr;102(14):5215-20. https://doi.org/10.1073/pnas.0501282102

108. Yasuda T, Miyachi S, Kitagawa R, Wada K, Nihira T, Ren YR, et al. Neuronal specificity of alpha-synuclein toxicity and effect of Parkin co-expression in primates. Neuroscience. 2007 Jan;144(2):743-53. https:// doi.org/10.1016/j.neuroscience.2006.09.052

109. Zetterstrom RH, Solomin L, Jansson L, Hoffer BJ, Olson L, Perlmann T. Dopamine neuron agenesis in Nurr ldeficient mice. Science. 1997 Apr;276(5310):248-50. https://doi.org/10.1126/science.276.5310.248

110. Kadkhodaei B, Ito T, Joodmardi E, Mattsson B, Rouillard C, Carta M, et al., Nurrl is required for maintenance of maturing and adult midbrain dopamine neurons. J Neurosci. 2009 Dec;29(50):15923-32. https://doi.org/10.1523/JNEUROSCI.3910-09.2009

111. Kadkhodaei B, Alvarsson A, Schintu N, Ramskold D, Volakakis N, Joodmardi E, et al. Transcription factor Nurrl maintains fiber integrity and nuclear-encoded mitochondrial gene expression in dopamine neurons. Proc Natl Acad Sci U S A. 2013 Feb;110(6):2360-5. https://doi.org/10.1073/ pnas. 1221077110

112. Le Pen G, Sonnier L, Hartmann A, Bizot JC, Trovero F, Krebs MO, et al. Progressive loss of dopaminergic neurons in the ventral midbrain of adult mice heterozygote for Engrailed1: A new genetic model for Parkinson's disease? Parkinsonism Relat Disord. 2008;14 Suppl 2:S107-11. https://doi. org/10.1016/j.parkreldis.2008.04.007

113. Nordstroma U, Beauvaus G, Ghosh A, Pulikkaparambil Sasidharan BC, Lundblad M, Fuchs J, et al. Progressive nigrostriatal terminal dysfunction and degeneration in the engrailedl heterozygous 


\section{Animal Models of Parkinson's Disease}

mouse model of Parkinson's disease. Neurobiol Dis. 2015 Jan;73:70-82. https://doi.org/10.1016/j. nbd.2014.09.012

114. Kurowska Z, Jewett M, Brattas PL, Jimenez-Ferrer I, Kenez X, Bjorklund T, et al. Identification of multiple QTLs linked to neuropathology in the engrailed-1 Heterozygous Mouse model of Parkinson's disease. Sci Rep. 2016 Aug;6:31701. https://doi.org/10.1038/srep31701

115. Baiguera C, Alghisi M, Pinna A, Bellucci A, De Luca MA, Frau L, et al. Late-onset Parkinsonism in NFkappaB/c-Rel-deficient mice. Brain. 2012 Sep;135(Pt 9):2750-65. https://doi.org/10.1093/brain/ aws 193

116. Zhou FM, Li L, Yue J, Dani JA. Transcription factor Pitx3 mutant mice as a model for Parkinson's disease. Front Biol. 2016 Dec;11(6):427-38. https://doi.org/10.1007/s11515-016-1429-8

117. Hwang DY, Fleming SM, Ardayfio P, Moran-Gates T, Kim H, Tarazi FI, et al. 3,4-dihydroxyphenylalanine reverses the motor deficits in Pitx3-deficient aphakia mice: Behavioral characterization of a novel genetic model of Parkinson's disease. J Neurosci. 2005 Feb;25(8):2132-7. https://doi.org/10.1523/ JNEUROSCI.3718-04.2005

118. Hynes M, Porter JA, Chiang C, Chang D, Tessier-Lavigne M, Beachy PA, et al. Induction of midbrain dopaminergic neurons by Sonic hedgehog. Neuron. 1995 July;15(1):35-44. https://doi. org/10.1016/0896-6273(95)90062-4

119. Ekstrand MI, Galter D. The MitoPark Mouse - An animal model of Parkinson's disease with impaired respiratory chain function in dopamine neurons. Parkinsonism Relat Disord. 2009 Dec;15 Suppl 3:S185-8. https://doi.org/10.1016/S1353-8020(09)70811-9

120. Cook R, Lu L, Gu L, Williams RW, Smeyne RJ. Identification of a single QTL, Mptpl, for susceptibility to MPTP-induced substantia nigra pars compacta neuron loss in mice. Brain Res Mol Brain Res. 2003 Feb;110(2):279-88. https://doi.org/10.1016/S0169-328X(02)00659-9

121. Jiao Y, Lu L, Williams RW, Smeyne RJ. Genetic dissection of strain dependent paraquat-induced neurodegeneration in the substantia nigra pars compacta. PLoS One. 2012;7(1):e29447. https://doi. org/10.1371/journal.pone.0029447 